\title{
All that glitters is not gold: silver leaf gilding, another means to an end
}

\author{
Tiago Dias ${ }^{1,2,3, *}$ \\ Elsa Murta² \\ Cristina Barrocas Dias ${ }^{3}$ \\ Vítor Serrão ${ }^{1}$ \\ ${ }^{1}$ ARTIS-IHA-FLUL - Instituto de História da Arte da Faculdade de Letras da Universidade de Lisboa, Portugal \\ ${ }^{2}$ Laboratório José Figueiredo, Direção-Geral do Património Cultural, Portugal \\ ${ }^{3}$ Laboratório Hercules, Universidade de Évora, Portugal \\ *tiago.dias.mail@gmail.com
}

\begin{abstract}
Complementing carved wood altarpieces and sculptures, the use of metallic leaves became paradigmatic of Portuguese religious ambiences during the 17th and 18th centuries. Although gold has always been favoured, alternative techniques to attain the desired golden lustre were developed simultaneously, mainly with the use of white metallic leaves covered with coloured glazes. Written historic references, present in various technical art texts, indicate that these imitation gildings have been a long time practice. Seldom mentioned, the silvering part of the process is generically described as identical to gilding, while much more attention is given to the golden glazes to be applied over the silvered surface, allowing for their material and technical evolution to be followed. Based on a survey of these historical references, an outline on these developments and the associated terminology is made, keeping in mind that the silver leaf's white glitter also shone on its own right.
\end{abstract}

Nem tudo o que brilha é ouro:

douramento com folha de prata, outro meio para um fim

\section{Resumo}

Complementando e enriquecendo retábulos e imagens, o uso de folhas metálicas tornou-se paradigmático dos interiores religiosos portugueses nos séculos XVII e XVIII. Apesar do ouro ter sido sempre favorecido desenvolveram-se, simultaneamente, técnicas alternativas para atingir o desejado lustre dourado, com recurso a folhas metálicas brancas cobertas com velaturas coloridas. Referências históricas, presentes em numerosos textos de técnicas artísticas, indiciam que estas técnicas de contrafação são praticadas desde há muito. Pouco mencionado, o processo de prateamento é genericamente descrito como idêntico ao de douramento, sendo dada muito mais atenção aos vernizes dourados a ser aplicados sobre a superfície prateada, o que permite que a sua evolução material e técnica seja seguida. Baseado num inquérito a estas referências, é feito um enquadramento destes desenvolvimentos e da terminologia associada, tendo presente que o fulgor alvo das folhas de prata também brilhou por direito próprio.

\section{Keywords}

Silvering

Gilding

Silver leaf

Gold varnish

Douradura

\section{Palavras-chave}

Prateamento

Douramento

Folha de prata

Verniz dourado

Douradura 


\section{Introduction}

This article presents preliminary information on the study of silver leaf gilding techniques, developed within the scope of the first author's ongoing $\mathrm{PhD}$ research, devoted to the use of silver leaf on Portuguese sculptures and altarpieces from the 17th and 18th centuries. Following on the oral communication presented at GILT-EnArt 2015 International Conference, new data is presented and discussed.

In order to outline and contextualize the use of this alternative gilding technique, a survey on European written sources was made with special focus on the timeframe between the 16th and 18th centuries. Nonetheless, it was deemed useful to trace back some of the earlier records on these practices, which could help further understand the material and technical evolution on these non-gold gilding techniques. The documentary records on yellow coloured glazes applied on to silvered surfaces - douradura - are the main focus of this study. References on the production and use of silver leaf are also presented, making an effort to clarify some of the ambiguous terminology usually associated with this technique, while shedding some light on the craftsmen involved.

\section{Leaf gilding techniques}

The use of metal leaves to cover and decorate surfaces has been practiced since antiquity, with the documented production and widely usage of gold leaf in Egyptian art [1, p. 76]. However, in Europe and over wooden sculptures, the documented use of leaf gilding is scarce, being only used in relatively small areas before the 12th century [2]. During this time, Myriam Serck-Dewaide hypothesised that silver leaf gilded areas might have been favoured over gold leaf gilding, which was reserved to smaller areas [2, p. 65]. Even if it is possible that this hypothesis is based on misleading results, as the author suggests, it shows that although a golden appearance was highly valued, alternative techniques were developed simultaneously to attain the desired golden lustre with less costly materials.

The gilding techniques in Europe were improved during the following centuries, and gilded areas became more monumental [2]. In Portugal, during the course of the 17th and 18th centuries, gilded surfaces became ubiquitous in the religious ambiences, covering wood carved altarpieces and sculptures and further adding to their spirituality and sumptuousness [3, p. I-183]. The use of gold and silver, coordinated with polychromy, conveyed symbolic connotations with the divine to the sculptural work, that are usually associated with these metals by their value and ability to reflect light [3; 4, p. 82]. During this period, silvered areas are reduced and usually serve well defined purposes such as the representation of metallic and ethereal elements (e.g. armours, swords and clouds).

At this time, Portuguese painters-gilders' technical repertoire should have also included the alternative gilding method of glazing silver leaf, since both materials and technical knowledge were at their disposal, as will

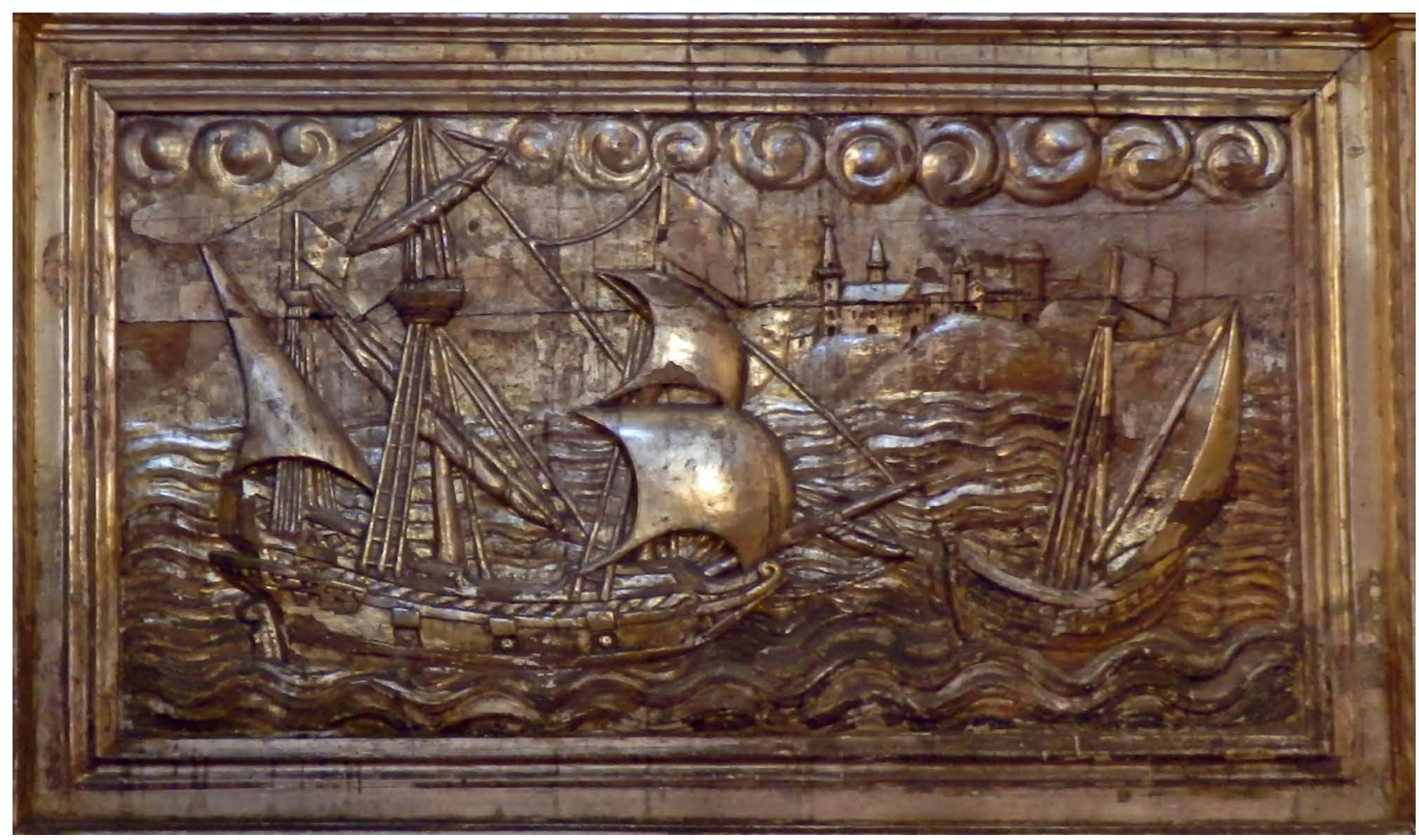

Figure 1. Detail of Nossa Senhora dos Mares altarpiece, Igreja Santa Cruz, S. Domingos Monastery, Viana do Castelo. Comissioned in 1622, silver leaf gilded wood. Photo: Tiago Dias. 
be shown in the following sections. We believe that most silver leaf gilded Portuguese objects remain nowadays unnoticed and therefore not properly documented, given that when a successful imitation is achieved the surfaces become very similar to "true gilding", hindering the technique's identification by the observer [5, p. 34]. Despite this, it is possible to identify several cases that resort to these silver leaf gilding techniques, both on altarpieces (Figure 1) and sculpture (Figure 2).

Silver's lower cost in comparison with gold was certainly a motivation for the use of this surrogate gilding technique. Francisco Pacheco confirms this when he writes that silver leaf gilding "is made in many parts of Castile, either to save gold, or for its lack"1 [6, p. 419]. The analysis of expense records that account for the purchase of both kinds of metal provides information on their price difference. For instance in Oporto, in 1542, the value of silver leaf was only a quarter of gold [7, p. I-69]. But, while the practice of gilding with silver leaves was recognized as an inexpensive alternative, its frailty given the silver's proneness to tarnish was also known, eventually leading to its banishment in Spanish contracts during the 17th century, for being "false work" that would quickly perish [8, p. 10].

\section{Terminology and disambiguation}

The ambiguity of the terminology associated with this alternative gilding technique is especially evident in the Portuguese language, leading to several misconceptions. Nowadays, the most commonly used expression to describe this technique is prata dourada that roughly translates to gilded silver, and often leads to confusion with the metalworking technique of covering silver objects with gold.

Expressions such as douramento com folha de prata and dourado com folha de prata are proposed to be used to describe, in Portuguese, the silver leaf gilding technique and the silver leaf gilded objects respectively. In these expressions the words dourado or douramento relate to the techniques' objective, to achieve a golden colour, while folha de prata (silver leaf) describes the material used to attain the metallic appearance.

Coloured glazes are usually named as varnish or lacquer in the historical sources [9, p. 65], and in several languages the nomenclature of the yellow coloured glaze used to give a golden appearance to silvered surfaces is different from other coloured glazes, revealing the composition's main purpose, which was to imitate gold [10, pp. 26-31; 11, pp. 34-35].

The Portuguese word for this golden coloured glaze used to imitate gold is douradura, defined in Raphael Bluteau's 1712 Vocabulário Português e Latino as a composition that "applied over any silvering [...] makes it properly look like gold, and over burnished silver is

1 Translated from the Spanish: "I esto se haze en muchas partes de Castilla, ô por ahorrar oro, ó por falta dèl".

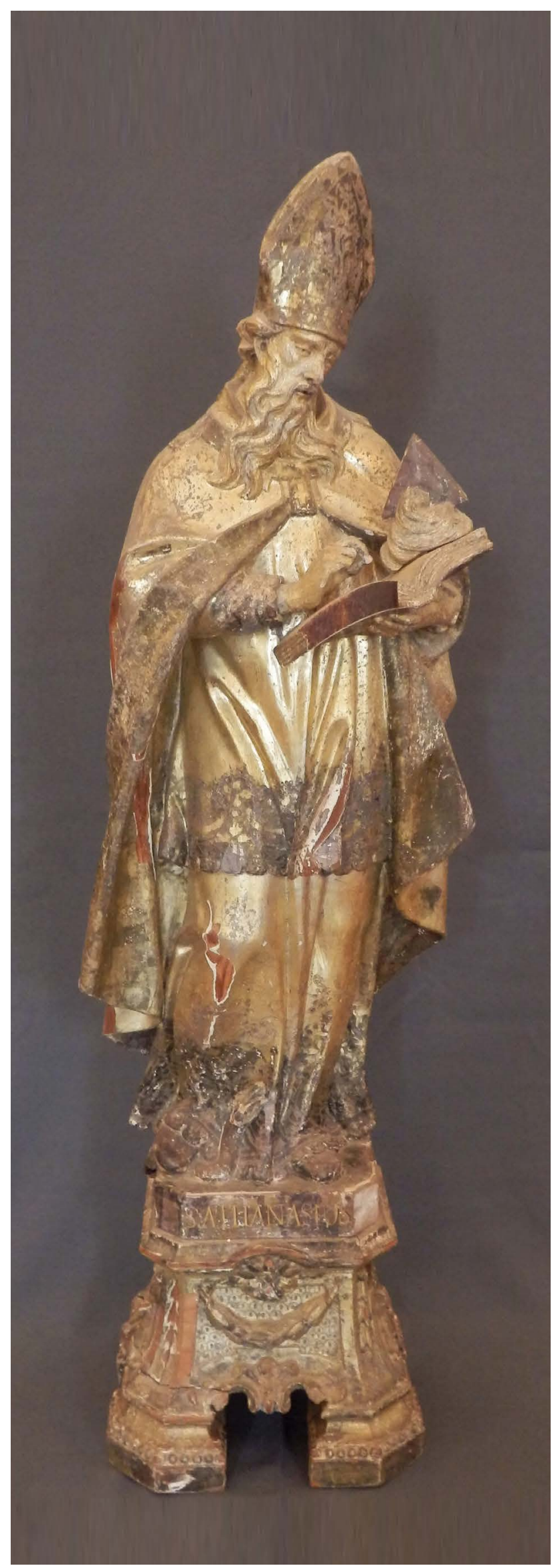

Figure 2. Saint Athanasius. Mafra National Palace, inv n. PNM 4. Silver leaf gilded wooden sculpture. Photo: Tiago Dias. 
best"2 [12, pp. 298-299]. It is also possible to find other Portuguese words that sometimes refer to douradura, both in material expense records where douradilha is mentioned [13, p. 523], and in technical art treatises translations where the term coradura is sometimes used [14, p. 29].

It should be noted that, although the term barniz Martin has been appointed by some authors as the Portuguese name for this glaze [10, p. 30; 11, p. 35], no references to support this could be found. Vernis Martin usually refers to a French varnish formulation, developed and patented by the family Martin in 1730 that imitated oriental lacquer work and knew great fame during the 18 th century $[15$, p. 4$]$.

\section{On the use of silver leaves}

\section{Portuguese artists and craftsmen}

Documentary sources on the activity of painter-gilders that clearly relate to the use of silver leaf are scarce. The known 1572 regulations for Lisbon's craftsmen offer little information concerning the painters' regiment, where painters-gilders were included, revealing only the examination requirements for those who wanted to gild and make estofado [16, pp. 104-105]. However, in other craft's regulations it is possible to find evidence on the production and use of silver leaf to imitate gold.

The goldbeaters' production of silver leaf is clearly documented on these regulations as part of the professional examination, where it is stated that to be approved as a goldbeater, one had to produce, among others, five hundred "thin" silver leaves "for painters" [16, pp. 25-26]. This indication reveals the differentiation of "thin" silver (and gold) leaves to be used by paintergilders and "thick" leaves in use by (metal) gilders.

This document also points to the use of silver for the production of ouro meão, bimetallic leaves of gold and silver known as zwishgold or oro di metà [17]. The production and commercialization of this substandard leaves was prohibited and heavily punished, on the count of its deceitfulness and low quality [16, p. 26].

References to the practice of glazing silver leaf to achieve a gold tone are found on the guadamecileiros regulations (leather workers and gilders) [16, pp. 9498]. Guadameci is most often silver leaf gilded, rarely resorting to gold $[18$, p. 5], so part of the examination of the craftsman consisted on silvering, burnishing and glazing the worked leather, implying that the examinee had to make his own douradura [16, p. 94]. While the nature of the douradura is not disclosed in this document,

2 Translated from the Portuguese: “Douradura. He uma composição [...] [que] sobre qualquer prateado de tempera, ou óleo se aplica \& o faz parecer propriamente ouro, \& sobre prata burnida, melhor". other sources provide information on the materials used, and this will be addressed on a following section.

On the context of this craft, silver leaf gilding was the more appropriate technique to be used, and other metallic leaves were banned. This is clearly stated on the regulations that forbade the use of tin leaves by the craftsman and denounced the entrance of guadameci "from beyond the realm with gilding of tin and not of silver as it should be, which is forgery"3 [16, p. 97].

\section{Laying the silver leaves}

Silver leaves can be applied with the purpose of giving a silvered look on to a surface, where the silvering (prateamento) is an end in itself. However, on the context of counterfeit gilding the silvered surface becomes part of the gilding process - a means to an end - providing the metallic appearance to be covered with a glaze of a golden yellow colour (douradura) [5, p. 34].

Although the douradura can be applied on water or oil silvering, the water silvering method is usually preferred, since it allows the surface to be burnished, "and over burnished silver is best" [12, p. 299; 19, p. 281]. On the count of being similar to the laying of gold leaf, the silvering process is seldom individualized on the documentary sources, which instruct on how to proceed with both metals simultaneously ("if you want to apply Gold or silver leaves" [19, p. 280]) or direct to proceed with silver as with gold ("regarding oil and water silvering, it is practised precisely as gilding: so everything that is said about one can equally be applied to the other" [20, p. 349]).

Water-gilding requires the wooden surface to be coated with a multi-layered preparatory structure, involving several procedures which include: sizing with animal glue, multiple ground layer application of gesso grosso followed by gesso mate and, finally, application of the bole [21, pp. 67-68]. The number and nature of the applied layers of each material may vary greatly, being a total of 15 layers considered ideal [22, p. 20].

Documentary sources advise on the use of bole with different colours if one is gilding or silvering: under the gold leaf warmer hues are recommended, from yellow to deep red, to contribute to the overall colour of the gilding; for silvering the sources from this period recommend white bole, or other white grounds such as lead white glue tempera, "grind [...] very fine lead white with water, and distemper it in weak glue [...] it will serve as bole" $[23$, pp. 165-166].

Given the thinness of the metallic leaves, the bole's colour has a strong impact on the final visual perception

3 Translated from the Portuguese: "vem guadamecijs de fora do reno cujo dourado he de estanho e não de prata como há de ser, o que he falsidade".

4 Translated from the French: "Broyez ensuite du blanc de plomb très-fin à l'eau, \& détrempez-le avec la colle plus foible ; donnezen deux couches sur les parties que vous voulez brunir, ce qui servira d'assiette". 
of the gilding [5, p. 33], so the use of white bole would increase the silvered surface's lightness and whiteness, while helping to conceal any small tears on the leaf. But if the intention is to create silver leaf gilding by glazing the silvered surface, a white bole would make it harder to achieve the warm gold colour, while making any small leaf tears much more visible - which has been observed during the reproduction of silvered mockups glazed with douradura. So, it would seem sensible that when the final intention is to achieve a gold colour, the silver leaf should have been applied over warm coloured boles similar to those used for gold.

After laying the silver leaves and with the selected areas burnished, the silvered surface would be ready to receive its coating. Silver's high reactivity and proneness to tarnish was recognized and the need to cover it was strongly advised, even when its colour was to be maintained, "silvering is susceptible to the bad air; if we want to preserve its silver colour, you must use a varnish of wine spirits" $[23$, p. 166].

\section{Douradura, gilding with silver}

\section{Historical background}

References on documentary sources about the glazing of white metallic surfaces to achieve a golden appearance are more frequent and seem to start at an earlier date than those references detailing the silvering process. To better understand how these coatings' formulations change through time, a brief overview on the earliest known related writings is made from a few selected European documentary sources up to the 15 th century.

One of the earliest references can be found on the Leyden papyrus X (c. 4th century) where among several chrysography references, a gilding solution is mentioned (recipe 75) that could also be applied on copper and silver objects [24, p. 34]. Although it is not yet a clear douradura but a type of oro musivo its use shows the practice of altering the colour of metallic surfaces using, among other ingredients, realgar and orpiment bound in gum tracaganth and diluted in goat bile. Some of the false chrysography recipes also reveal the use of natural dyes bound in egg or diluted in gal, to mimic a golden appearance (e.g. recipes 39 and 74) [24, pp. 28, 74-75]. These compositions will continue to be mentioned in latter documents, especially with the purpose of parchment gilding.

The oldest known reference to a yellow oil medium glaze to apply over tin leaves, giving them a golden colour, is found on the Compositiones ad tingenda musiva also referred to as Lucca Ms or Codex Lucensis 490 (c. 8-9th centuries) [25, p. 495]. It is composed of a resin mixed with linseed oil and water, and coloured

5 Translated from the French: "L'argenture est susceptible du mauvais air ; si on veut conserver sa couleur d'argent, il faut y passer un vernis à l'esprit-de-vin". by saffron and orpiment [26, pp. 67-68, 129]. A very similar recipe is given in Mappae Clavicula under the name Tinctio stagnee petale (Phillips-Corning MS, c. 8th12th centuries) [27, p. 47], and Mary Merrifield points out that it is also present on both Eraclius' De Coloribus et Artibus (13th century) and Peter of St Audemar's De Coloribus Faciendes (13th to 14th centuries) under the name auripetrum, "a varnish to which a golden colour was imparted by saffron, and which, when spread over tinfoil, was employed to imitate gold", further implying that the several copies of the recipe are "proof of the extent to which it was used" [28, p. I-114]. Although one of the auripetrum formulas given by Peter of St Audemar corresponds to a similar composition, saffron distempered in liquid varnish [28, Vol. I, p.158], on Eraclius' work the recipe calls for different materials such as myrrh, aloes and blackthorn bark [28, Vol. I, p. 240].

The De Coloribus Faciendes presents four other variations for tin coating to give it a gold colour that always involve the dipping of the foil in a solution, be it for dying with saffron, aloes or black plum bark in water, or to be varnished in linseed oil with resin and vernix (sandarac) dyed with black plum bark [28, Vol. I, pp. 160-165]. Noteworthy is the reference to the use of silver alongside tin on "the manner of beating out tin-plates, so as to appear gilt, to use in painting, on account of the price of gold" [28, p. I-160].

The use of aloes as dye seems to be common in oil based glazes from this time forth. On the Livro de Como se Fazem as Cores (c.14th to 15th century), it is possible to find one of the earliest Portuguese references to a glaze made with grassa ${ }^{6}$ and linseed oil, using aloes in powder to make "the colour of gold" [29, p. 222]. Grassa has been pointed out by several authors to be a common name for sandarac, and Andrés de Lagunas underlines this on his translation of Dioscorides' De Materia Medica, explaining that grassa is the juniper's gum also called vernix or sandarax and is used to make varnish with linseed oil [30, p. 62]

This recipe from the Livro de Como se Fazem as Cores names the yellow glaze as doiradura and speaks of its use over tin and silver leaves, allowing to relate this formulation with the douradura referred to on the guadamecileiros regiment exam [16, p. 94; 18, p. 5], and the varnish described by Filipe Nunes to be used by craftsmen of guadamexins (on this case, without aloes) $[21$, p. 72].

\section{The written sources from the 16 th to the 18th centuries}

During the 16th to the 18 th centuries the number and variety of formulas to make glazes of golden yellow colour increased enormously. The ongoing survey of the numerous documentary sources is therefore approached

6 From the transliteration "garas ${ }^{a} \mathrm{~h}$ de nobra" or "gras ${ }^{\mathrm{a}} \mathrm{h}$ ", that can be understood as "grassa". 
on a more systematic manner. Information is being collected from technical art treatises and manuals mainly published in the south European Countries during this time span, given the close similarity of gilding materials and techniques described with those expected to have been available and used in Portugal [31]. The publishing language of the treatises and the translated editions also played an important role on their use and understanding, with some languages being more accessible to the Portuguese readers, namely Spanish, French and Italian [32, p. 22]. Although English copies are not usually found in Portuguese libraries of this period [32, p. 23], three English sources were taken into account, given their seemingly important contribution on the diffusion of lacquer formulations to be used as douradura.

Out of the numerous publications consulted so far, 21 presented guidelines on the making of gold coloured varnishes. It is interesting to notice that while some treatises offer instructions on how to use the glazes, they make no references on the douradura's formulation, as in Francisco Pacheco's Arte de la Pintura [6]. All the recipes used to convey a golden colour on metallic surfaces were considered, since we believe that most of the glazes used over metallic objects could have also been employed on these surrogate gilding techniques, provided that the object's submersion was not required.

Using these guidelines, 89 recipes were found, in a time span reaching from 1557's French edition of Alessio Piamontese's Les Secrets, to the 1794's anonymous Segredos Necessários para os Oficios, Artes e Manufacturas. A list of these sources is presented in the Appendix. Although this data still needs further interpretation and study, several considerations can already be made on the production of douradura.

Recipes of the above mentioned oil glazes will continue to be presented until the end of the 18th century (Figures $3 \mathrm{a}$ and $4 \mathrm{a}$ ) and are sometimes associated with the guadameci technique on their description "varnish with which leather is dyed with gold colour"7 [33, pp. 66-67]. Up to 1750 , their composition usually involves only few materials: sandarac and/or pine resin (to which Greek pitch and mastic can be added) are boiled with linseed oil and the glaze is coloured most often with only aloes, to which some recipes add saffron and turmeric [34, p. 103; 35, pp. 282-283].

On the second half of the 18th century the most often referred combination to be used with linseed oil is amber and shellac, seemingly by French influence of the works of Delormois and Watin and their formulas for vernis gras à l'or [23, pp. 238-239; 36, p. 142; 37, pp. 84-86]. As for dyeing, although references to the single use of aloes are still made, the gold colour is also achieved by the combination of annatto, dragon's blood, gamboge and saffron (Figure 4a) [23, pp. 238-239].
Alcohol or spirit based glazes would slowly become dominant, in great part due to the crescent interest in oriental lacquers and the attempts to replicate them in Europe [38, pp. 272-275]. Among the references studied, the earliest indication of an alcoholic or spirit based varnish is in Alessio Piemontese's Les Secrets, where benzoin resin is dissolved in spirit and coloured with saffron "to make beautiful varnish, to varnish the said gold"8 [34, pp. 86-87]. If before the 1700's spirit based glazes only represented around a third of the references (and the majority of these came from Stalker and Parker's work), during the 18 th century spirit based glazes become half of the total references.

Shellac was clearly favoured to make this spirit glazes and its use became predominant over time, often being used on its own [39, p. 878]. Benzoin and sandarac were also used on their own, while mastic and amber were employed in combinations with the above mentioned materials (Figure 3b) [33, p. 30].

On the 16th and 17th centuries references, four dyes are mentioned for spirits glazes; saffron, turmeric, gamboge and dragon's blood to which we must add the colour named ornator mentioned by Stalker \& Parker and Salmon [39, p. 879; 40, p. 63]. In the 18 th century aloes and annatto are also mentioned in several combinations (Figure 4b).

The use of essential oils on glaze production is also mentioned throughout this timeframe. Turpentine and spike lavender oil are referred as solvents in several recipes, although in much smaller number than the previously mentioned oil and spirits [19, pp. 281-282; 41, p. 51]. Amber, benzoin, mastic, pine resin, sandarac and sugar are mixed in different combinations (figure 1c) and it is noteworthy that - among the recipes collected - the first reference to shellac appears in Domenico Auda's Breve Compedio de Marivigliosi Secreti, where it is dissolved in turpentine along with sugar and dyed with aloes [42, p. 143].

The majority of these essential oil glazes are coloured with only aloes (Figure 4c), although one recipe calls for turmeric [42, pp. 142-143], and another for a combination of dragon's blood and gamboge [19, pp. 281-2].

On the colouring of all the kinds of glazes it is interesting to notice that just over half the recipes (45 out of 89) call for the combination of at least two dyes to achieve the golden hue. While the most often referred is saffron, in 45 recipes, is it mentioned as the single dying material only six times. Aloes was most referred to be used on its own, 24 times in a total of 38 of references.

The dying method seems to have also suffered some changes. If on the earlier recipes all the ingredients were putted together in one vessel, on the later references the dye was previously extracted with a solvent (usually ethanol or spirits), and later the coloured solution was
7 Translated from the Italian: "Vernice, com cui si tingono le pelli di colore d'oro".
8 Translated from the French:"Pour faire tre-beau vernis, pour vernir le-dit or". 
a
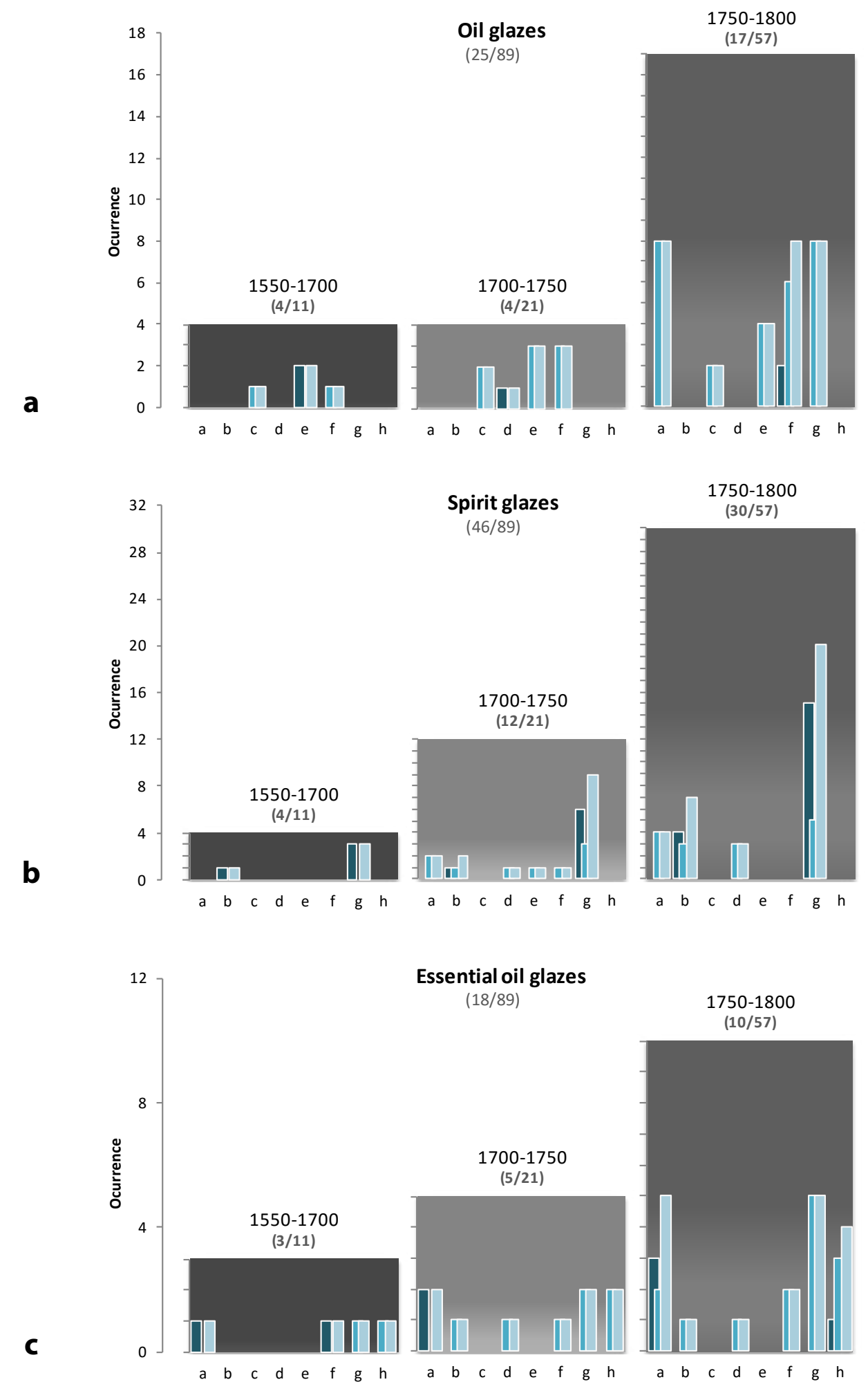

Substances

$\begin{array}{lll}\text { a-amber } & \text { e-pine resin } & \text { only substance used } \\ \mathrm{b} \text { - benzoin } & \mathrm{f} \text {-sandarac } & \text { used combined with others } \\ \mathrm{c} \text { - Greek pitch } & \mathrm{g} \text {-shellac } & \text { total use } \\ \mathrm{d} \text { - mastic } & \mathrm{h} \text {-sugar } & \end{array}$

Figure 3. Main medium materials occurrence on the consulted documentary sources, sorted by time period and type of use in the three main kinds of glaze: $a$ ) oil glazes, $b$ ) spirit glazes and $c$ ) essential oil glazes. Numbers in brackets indicate the number of references to a given type of glaze per total references in a given time period. 


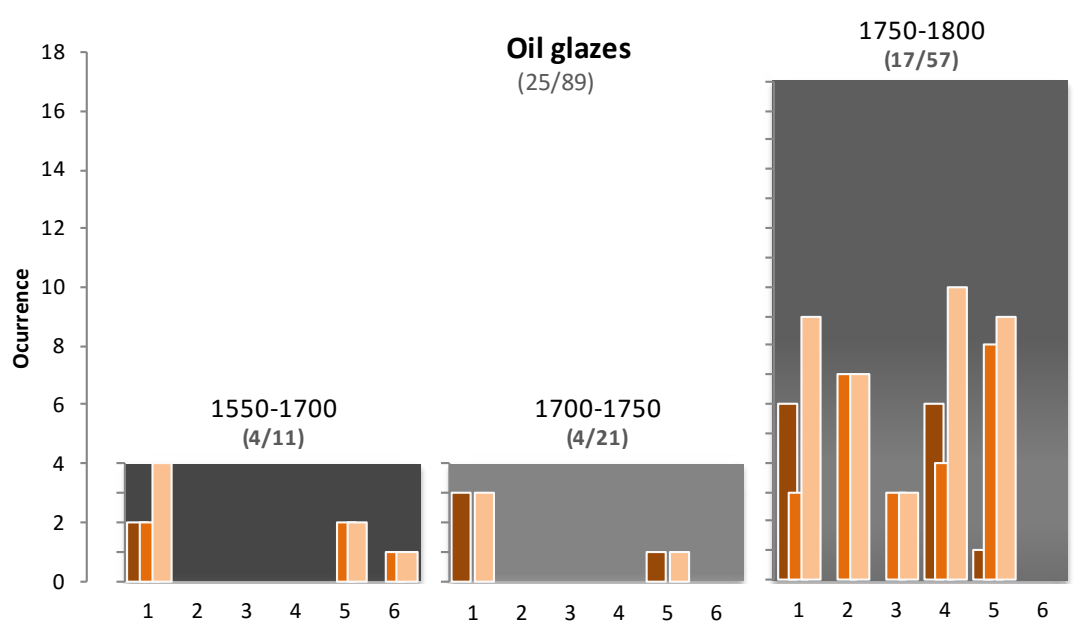

b
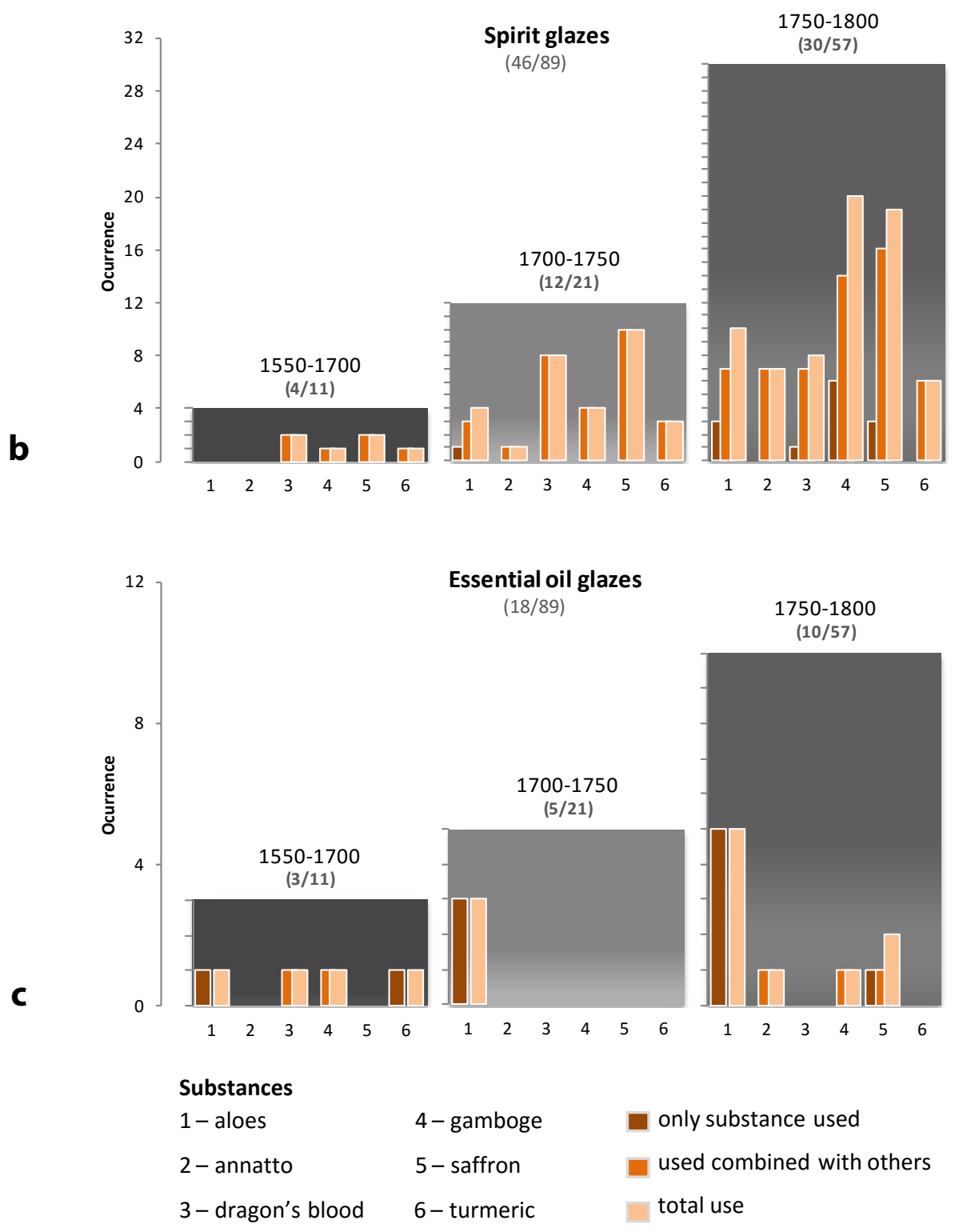

Figure 4. Main dye materials occurrence on the consulted documentary sources, sorted by time period and type of use in the three main kinds of glaze: $a$ ) oil glazes, $b$ ) spirit glazes and $c$ ) essential oil glazes. Numbers in brackets indicate the number of references to a given type of glaze per total references in a given time period. 
mixed with the other glaze ingredients, allowing for a better control on dying [43, pp. 54-55].

\section{Final remarks}

The practice of silver leaf gilding, as a surrogate technique for gilding, has been often overlooked and misinterpreted. Scarce information on terminology, materials and processes obstructs the correct interpretation of documents and objects and, when the technique's objective is achieved - to simulate gold gilding - it becomes dissimulated, hindering identification. However, even when recognized silver leaf gilding is often deemed of lesser importance, as a forgery technique for true gilding.

Documentary sources point out to the antiquity of these techniques, allowing to trace their development and infer on their importance. These historic references also reveal that great care was placed on achieving a gold coloured glaze with good properties, and it is important to remember that the douradura is an intrinsic part of the technique and therefore of the object itself, and conservation treatments should respect this often fragile layer.

While providing essential information for the identification and interpretation of silver leaf gilding techniques, through the ongoing documentary survey alone it is not possible to establish with certainty when and how the referenced recipes have been executed. Within the scope of the firstly mentioned study on the use of silver leaf in Portuguese objects from the 17th and 18th centuries, further studies on silvered and silver leaf gilded sculptures and altarpieces are in progress with the objective of revaluating the occurrence and importance of these techniques in the Portuguese artistic production.

\section{Acknowlegments}

The authors acknowledge the support of the Portuguese Foundation for Science and Technology (FCT) through the grant financed by the Ministry of Education and Science attributed to Tiago Dias (SFRH/BD/78214/2011). We also gratefully acknowledge the support given towards this project by the several institutions that facilitated access and information on the objects under study namely, regarding the illustrated objects on this article, Nossa Senhora de Monserrate parish (Viana do Castelo) and Mafra National Museum.

\section{References}

1 Oddy, A., 'Gilding through the ages: an outline history of the process in the Old World', Gold Bulletin 14(2) (1981) 75-79, doi:10.1007/BF03214601.

2 Serck-Dewaide, M., 'The history an conservation of the surface coating on European gilded-wood objects', in Gilded
Wood: Conservation and History, Sound View Press, Connecticut (1991) 65-78.

3 Ferreira-Alves, N. M., A Arte da Talha no Porto na Época Barroca: Artistas e Clientela, Materiais e Técnica, Arquivo Histórico, Câmara Municipal do Porto, Porto (1989).

4 Clark, G., Symbols of Excellence: Precious Materials as Expressions of Status, Cambridge University Press, Melbourne (1986).

5 Cession, C., 'The surface layers of baroque gildings: examination, conservation, restoration', in Cleaning, Retouching and Coatings: Contributions to the 1990 IIC Congress, ed. J. S. Mills, P. Smith, IIC, London (1990) 3335, doi:10.1179/sic.1990.35.s1.008.

6 Pacheco, F., Arte de la Pintvra, Sv Antigvedad, y Grandezas, Sevilla (1649), http://archive.org/details/gri_ artedelapint00pach (accessed 2015-11-18).

7 Brandão, D. P., Obra de Talha Dourada, Ensamblagem e Pintura na Cidade e na Diocese do Porto: Documentação, 4 vols, Porto (1984).

8 Bruquetas, R., 'Los gremios, las ordenanzas, los obradores', in La Pintura Europea sobre Tabla en los Siglos XV, XVI y XVII: Estudios Técnicos, Ministerio de Cultura, Madrid (2010) 20-24

9 Richter, M., 'Art-technological source research and scientific examination: a comparative study on the thecnique of coloured glazes applied on metal leaf', in Lüsterfassugen des Barok un Rokoko - Coloured Glazes on Metal Leaf from the Baroque and Rococo, eds. E. Emmerling, M. Kühlental, M. Richter, München (2013) 39-83.

10 Fuente Rodríguez, L. Á., 'Los metales plateados como policromía (las corladuras): análisis-experimentación y restauración', PhD thesis, Universidad del País Vasco (1999).

11 Richter, M., 'Coloured glazes on metal leaf: definition and terminology', in Lüsterfassugen des Barok un Rokoko - Coloured Glazes on Metal Leaf from the Baroque and Rococo, eds. E. Emmerling, M. Kühlental, M. Richter, München (2013) 33-37.

12 Bluteau, R., Vocabulario Portuguez \& Latino, 8 vols., Collegio das Artes da Companhia de Jesus, Coimbra (17121728), http://purl.pt/13969.

13 Cardoso, M. I. F. P., 'Gesso layers on Portuguese Baroque altarpieces: materials, practices and durability', $\mathrm{PhD}$ thesis, Institute of Archaeology, University College London, London (2010).

14 Montón, B., Segredos das Artes Liberais, e Mecanicas, Lisboa (1746).

15 Ordóñez Goded, C., 'El mueble lacado. Métodos europeos hasta el siglo XIX', in Curso sobre Mobiliario Antiguo CD, GE Publicaciones, Madrid (2004), http://ge-iic.com/index. php?option $=$ com_content $\&$ task $=$ view $\&$ id $=39 \&$ Itemid $=40$ (accessed 2015-11-18).

16 Correia, V., Livro dos Regimentos dos Officiaes Mecanicos da Mui Nobre e Sempre Leal Cidade de Lisboa (1572), Imprensa da Universidade, (Coimbra) 1926.

17 Eveno M.; Martin, E., 'Les feuilles mixtes or-argent en peinture de chevalet', in ICOM Committee for Conservation 11th Triennial Meeting, Edinburgh, Scotland, ed. J. Bridgland, James \& James, London

18 Pereira, F., 'O comércio de 'couro dourado'/guadameci entre Córdova e Lisboa: um contrato de venda de 1525', Medievalista Online 13 (2013), http://www2.fcsh.unl.pt/ iem/medievalista/MEDIEVALISTA13/pereira1304.html (accessed 2015-11-18).

19 Grez, B. D., Traité sur la Peinture Pour en Apprendre la Téorie et Se Perfectionner Dans la Pratique, Toulouse (1699), https://archive.org/details/traitesurlapeint00dupu (accessed 2015-11-18). 
20 Macquer, P., Dictionnaire Portatif des Arts et Métiers, Amsterdam (1767), http://gallica.bnf.fr/ark:/12148/ bpt6k6386190r.r=macquer.langPT (accessed 2015-11-18).

21 Nunes, F., Arte da Pintura. Symmetria, e Perspectiva, Pedro Crasbeek, Lisboa (1615), http://ciarte.no.sapo.pt/recursos/ tratados/tratados 1.html\#N (accessed 2015-11-18).

22 Ferreira-Alves, N. M., 'O douramento e a policromia no Norte de Portugal à luz da documentação dos séculos XVII e XVIII', in Policromia: a Escultura Policromada Religiosa dos Séculos XVII e XVIII - Estudo Comparativo das Técnicas, Alteracões e Conservação em Portugal, Espanha e Bélgica, ed. A. I. Seruya, Insituto Portugês de Conservação e Restauro, Lisboa (2004) 17-22.

23 Watin, J.-F., L’Art du Peintre, Doureur, Vernisseur., 2nd ed., Paris (1774), https://archive.org/details/ lartdupeintredor00wati (accessed 2015-11-18).

24 Caley E. R.; Jensen, W. B., The Leyden and Stockholm Papyri: Greco-Egyptian Chemical Documents from the Early 4th Century AD, University of Cincinnati, Cincinati (2008), http://www.che.uc.edu/jensen/W. B. Jensen/Books/ Leyden \& Stockholm Papyri.pdf (accessed 2015-11-18).

25 Pellizzari, A., I Trattati Attorno le Arti Figurative in Italia e Nella Penisola Iberica Dall' Antichita Classica al Rinascimento e al Secolo XVIII, Societá editrice F. Perrella, Napoli (1915), https://archive.org/details/ itrattatiattorno01pelluoft (accessed 2015-11-18).

26 Burnam, J. M., A Classical Technology. Edited from Codex Lucensis, 490, The Gorham Press, Boston (1920), http://hdl. handle.net/2027/uc2.ark:/13960/t3kw5913c (accessed 201511-18).

27 Phillips, T., 'Mappae Clavicula; a manuscript treatise on the Preparation of pigments, and on various processes of the decorative arts practised during the middle ages', Archaeologia 32 (1847) 183-244, https://archive.org/details/ archaeologiaormi32sociuoft (accessed 2015-11-18)

28 Merrifield, M. P., Original Treatises, Dating from the XIIth to the XVIIIth Centuries, on the Arts of Painting, 2 vols., London (1849), https://archive.org/details/ originaltreatis00merrgoog, https://archive.org/details/ originaltreatis01merrgoog (accessed 2015-11-18).

29 Strolovitch, D. L., 'O libro de komo se fazen as kores das tintas todas (transliteration)', in The Materials of the image - As Matérias da Imagem, ed. L. U. Afonso, Cátedra de Estudos Sefarditas «Alberto Benveniste» FL-UL, Lisboa (2010) 213-223.

30 Dioscórides, Acerca de la Materia Medicinal y de los Venenos Mortiferos, Anvers (1555), http://bdh.bne.es/ bnesearch/detalle/bdh0000037225 (accessed 2015-11-18).

31 Serck-Dewaide, M., et al, 'Les techniques utilisées dans l'art baroque religieux des XVIIe et XVIIIe siècles au Portugal, en Espagne et en Belgique', in Policromia: a Escultura Policromada Religiosa dos Séculos XVII e XVIII - Estudo Comparativo das Técnicas, Alterações e Conservação em Portugal, Espanha e Bélgica, ed. A. I. Seruya, Insituto Portugês de Conservação e Restauro, Lisboa (2004) 119155.

32 Rodrigues, A. D., 'The circulation of art treatises in Portugal between the XV and the XVIII centuries: some methodological questions', in Tratados de Arte em Portugal, eds. R. Moreira, A. D. Rodrigues, Scribe, Lisboa (2011) 2142.

33 Bonanni, F., Trattato Sopra la Vernice Detta Comunemente Cinese, 2nd ed., Roma (1731), http://archive.org/details/ trattatosopralav00buon (accessed 2015-11-18).

34 Piemontese, A., Les Secrets de reverend signeur Alexis Piemontois, de l'imprimerie de Christofle Plantin, Anvers (1557), http://alfama.sim.ucm.es/dioscorides/consulta_libro. asp?ref $=X 533303655 \&$ idioma $=0$ (accessed 2015-11-18).

35 Falloppio, G., Secreti Diuersi et Miracolosi Raccolti dal Falopia, Venetia (1687), https://books.google.
com/books?id=jHY4fxJEneUC (accessed 2015-1118).

36 Delormois, M., Le Vernisseur Parfait, ou, Manuel du Vernisseur, Paris (1771), http://archive.org/details/ levernisseurparf00delo (accessed 2015-11-18).

37 Watin, J.-F., L'Art de Faire et d'Employer le Vernis, Paris (1772), https://archive.org/details/lartdefaireetdem00wati (accessed 2015-11-18).

38 Fuente Rodríguez, L. Á 'Corlas o corladuras', in Tratado del Dorado, Plateado y Su Policromía: Tecnología, Conservación y Restauración, 2 nd ed., ed. E. G.-A. Martínez Editorial Universitat Politècnica de València, Valencia (2011) 265-286.

39 Salmon, W. Polygraphice., 8th ed., London (1701), https:// archive.org/details/polygraphiceor00salm (accessed 201511-18).

40 Stalker, J.; Parker, G., A Treatise of Japaning and Varnishing, Oxford (1688), http://archive.org/details/ treatisejapanin00Stal (accessed 2015-11-18).

41 Agricola, F.; Buonanni, F., Trattenimenti sulle Vernici, Ravenna (1788), https://archive.org/details/ trattenimentisul00agri (accessed 2015-11-18).

42 Auda, D., Breve Compendio di Maravigliosi Secreti, Venetia (1668), https://books.google.pt/books?id=JY48AAAAcAAJ (accessed 2015-11-18).

43 Stooter, J., Arte de Brilhantes Vernizes, Anveres (1729), http://ciarte.no.sapo.pt/recursos/tratados/tratados1.html\#S (accessed 2015-11-18).

\section{Appendix}

Sources from the 16th to the 18th centuries in chronological order of the source's first edition, with reference to the consulted edition or translation, noted with the number of douradura recipes found and respective page numbers:

1555. Alessio Piemontese. Dé secreti del reuerendo donno Alessio Piemontese

- Piemontois, A., Les secrets de reverend signeur Alexis Piemontois, de l'imprimerie de Christofle Plantin, Anvers (1557).

- Recipes: 4 (pp. 80-81, 86-87, 87-88, 103).

1561. Isabella Cortese. I Secreti de la Signora Isabella Cortese

- Cortese, I., I Secreti de la Signora Isabella Cortese, Ne' Quali si contengono cose minerali, medicinali, arteficiose, \& Alchimiche, \& molte de l'arte profumatoria, appartenentia ogni gran Signora. Com altri bellisimi Secreti aggiunti, Appresso Giovanni Bariletto, Venetia (1565).

- Recipes: 1 (pp. 88-89).

1563. Gabrielle Fallopio (?). Secreti diuersi et miracolosi

- Falloppio, G., Secreti diuersi et miracolosi raccolti dal Falopia, appresso Giuseppe Tramontin, Venetia (1687).

- Recipes: 1 (pp. 282-283).

1652. Domenico Auda. Breve compendio di marivigliosi secreti 
- Auda, D., Breve compendio di maravigliosi secreti, Apresso Giacomo Zattoni, Venetia (1668).

- Recipes: 2 (pp. 142-143).

1672. William Salmon. Polygraphice

- Salmon, W., Polygraphice: or, The Arts of Drawing, Engraving, Etching, Limning, Painting, Vernishing, Japaning, Gilding, \&c., $8^{\text {nd }}$ ed., Printed for A. and J. Churchill, and J. Nicholson, London (1701).

- Recipes: 5 (pp. 872,873,878-879).

1688. John Stalker and George Parker. A Treatise of Japaning and Varnishing

- Stalker, J.; Parker, G., A Treatise of Japaning and Varnishing : Being a Complete Discovery of Those Arts, John Stalker and George Parker, Oxford (1688).

- Recipes: 3 (p. 63).

1699. Bernard Dupuy du Grez. Traité sur la peinture

- Du Grez, B. D., Traité sur la peinture pour en apprendre la téorie et se perfectionner dans la pratique, Chez la veuve de J. Pech \& A. Pech, Toulouse (1699).

- Recipes: 1 (pp. 281-282).

1720. Filippo Bonanni. Trattato sopra la vernice detta comunemente cinese

- Bonanni, F., Trattato sopra la vernice detta comunemente cinese, $2^{\text {nd }}$ ed., Per Antonio de' Rossi, Roma (1731).

- Recipes: 7 (pp. 30-33, 66-67).

1729. João Stooter. Arte de Brilhantes vernizes, \& das tinturas

- Stooter, J., Arte de Brilhantes vernizes, \& das tinturas, por la viúva de Henrico Verdussen, Anveres (1729).

- Recipes: 1 (pp. 54-55).

1734. Bernardo Montón. Secretos de artes liberales, y mecanicas

- Montón, B., Secretos de artes liberales, y mecanicas, recopilados, y traducidos de varios, y selectos authores, que tratan de phisica, pintura, arquitectura, optica, chimica, doradura, y charoles, con otras varias curiosidades ingeniosas. En la oficina de Antonio Marin. Madrid (1734).

- Recipes: 1 (p. 21).

1735. Genaro Cantelli. Tratado de barnizes y charoles

- Translation of Bonanni 's Trattato sopra la vernice.

- Cantelli, G., Tratado de barnizes y charoles : en que se da el modo de componer uno perfectamente, parecido al de la China, y muchos otros que sirven à la pintura, al dorar, y abrir, con otras curiosidades, Por Joseph Estevan Dolz Valencia (1735).

- Recipes: 7 (pp. 13-15, 71, 73).
1755(?). Francisco Vicente Orellana. Tratado de barnices, y charoles

- Translation of Bonanni 's Trattato sopra la vernice and Boutet's Traité de Mignature (?).

- Orellana, F. V., Tratado de barnices, y charoles, $2^{\text {nd }}$ ed., en la imprenta de Joseph Garcia, Valencia (1755).

- Recipes: 7 (pp. 14-15, 65, 70, 72, 124-125).

1758. Robert Dossie. The Handmaid to the Arts

- [Dossie, R.], The Handmaid to the Arts,vol I, London (1758).

- Recipes: 4 (pp. 430-432).

1758. Giuseppe Galeazzi. Trattato di miniatura

- Translation of Boutet's Traité de Mignature.

- [Boutet, C].; Galeazzi, G. (trad.), Trattato di miniatura, per imparare facilmente a dipingere senza maestro e la dichiarazione di molti segreti per fare i più bei colori, colla maniera di far l'oro brunito, l'oro in conchiglie, e la vernice della China, Nella stamperia di Giuseppe Galeazzi, Milano (1758).

- Recipes: 1 (pp. 147-148).

1764. Joaquim Feio Serpa. Segredos das Artes Liberaes, e Mecanicas

- Translation of Montón's Secretos de artes liberales, y mecanicas.

- Montón, B; Serpa, J. (trans.), Segredos das Artes Liberaes, e Mecanicas, Recopilados,m e Traduzidos de vários Autores selectos, que trataõ de Fisica, Pintura, Architectura, Optica, Quimica, Douradura, $e$ Acharoado, com outras varias curiosidades proveitosas, e divertidas. Na Offic. De Domingos Gonsalves. Lisboa (1764).

- Recipes: 4 (pp. 29, 35, 154, 156).

1764. Angelo Maria Alberto Guidotti. Nuovo trattato di qualsivoglia sorte di vernici...

- Guidotti, A. M. A., Nuovo trattato di qualsivoglia sorte di vernici, comunemente dette della China, formate secondo, che si pratica in Francia, in Inghilterra, ed in altre parti dell'Europa, Per Lelio dalla Volpe, Bologna (1764).

- Recipes: 1 (p. 70).

1771. M. Delormois. Le Vernisseur Parfait, Ou, Manuel Du Vernisseur

- Delormois, M., Le Vernisseur Parfait, Ou, Manuel Du Vernisseur, chez Charles-Antoine Jombert père, Paris (1771).

- Recipes: 5 (pp. 74-75, 142-144, 189-192).

1772. Jean-Félix Watin. L'art de faire et d'employer le vernis

- Watin, J.-F., L'art de faire et d'employer le vernis, ou, L'art du vernisseur, auquel on a joint ceux $d u$ peintre et du doreur, Chez Quillau. Paris (1772). 
- Recipes: 5 (pp. 39, 80, 84-86).

1774. Jean-Félix Watin. L'art du peintre, doreur, vernisseur

- Watin, J.-F., L'art du peintre, doreur, vernisseur : ouvrage utile aux artistes \& aux amateurs qui veulent entreprendre de peindre, dorer \& vernir toutes sortes de sujets en bâtiments, meubles, bijoux, équipages, \&c., Chez Grangé, Paris (1774).

- Recipes: 2 (pp. 231-232, 238-239).

1788. Francesco Agricola. Trattenimenti sulle vernici

- Agricola, F.; [Buonanni, F.], Trattenimenti sulle vernici, ed altre materie utili, e dilettevoli sparse nelle opere di molti accreditati autori: particolarmente nel trattato assai stimato del $P$. Filippo Bonanni, Nella stamperia Roveri presso di Fratelli Fava, Ravenna, (1788).

- Recipes: 21 (pp. 50-55, 83-85)

1794. Anonimous. Segredos necessários para os oficios, Artes e manufacturas
- Anon., Segredos necessários para os oficios, Artes e manufacturas e para muitos objectos sôbre a economia doméstica, Offic. de Simão Thaddes Ferreira, Lisboa (1794).

- Recipes: 9 (pp. 104-106, 109, 116-118, 125-126, 255-257).

Received: 2015-07-10

Revised: 2015-11-18

Accepted: 2015-12-21

Online: $2015-12-30$

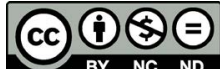

This work is licensed under the Creative Commons Attribution-NonCommercial-NoDerivatives 4.0 International License. To view a copy of this license, visit http://creativecommons.org/licenses/by-nc-nd/4.0/deed.en. 